\title{
Aberrant FGF15/FGFR4 Signaling Worsens Nonalcoholic Steatohepatitis Severity in FGF21KO Mice
}

\section{Youxi Yu}

Jilin University First Hospital

Xiaoju Shi

Jilin University First Hospital

Qianqian Zheng

China Medical University

\section{Xingtong Wang}

Jilin University First Hospital

\section{Xingkai Liu}

Jilin University First Hospital

Min Tan

University of Louisville School of Medicine

Guoyue Lv

Jilin University First Hospital

Ping Zhang

Jilin University First Hospital

Robert C. Martin

University of Louisville School of Medicine

Yan Li ( $\nabla$ yan.li@louisville.edu )

University of Louisville https://orcid.org/0000-0001-5584-1964

\section{Research}

Keywords: Fibroblast growth factor 15/19, Fibroblast growth factor 21, Nonalcoholic steatohepatities, Nonalcoholic fatty liver disease, Bile acid

Posted Date: January 18th, 2021

DOl: https://doi.org/10.21203/rs.3.rs-146881/v1

License: (c) (1) This work is licensed under a Creative Commons Attribution 4.0 International License. 


\section{Abstract}

\section{Background}

Pharmacological application of the endocrine fibroblast growth factor15/19 (FGF15/19) and FGF21 holds great promise to be effective therapeutic agents for treating nonalcoholic steatohepatitis (NASH), which is the most severe form of non-alcoholic fatty liver disease (NAFLD) and accepted as a potential precursor of hepatocellular carcinoma (HCC). In our previous studies, we found that FGF21 played a key role in preventing the development of NASH, however, the FGF15/19 mediated-FGFR4 signaling worsened $\mathrm{NASH}$ and even contributed to the NASH-HCC transition.

Methods

NASH models were established in FGF21KO mice fed with high fat methionine-choline deficient (HFMCD) diet to investigate FGF15/FGFR4 signaling during NASH development. We sought to determine whether FGF15/FGFR4 signaling could alleviate or aggravate NASH in the FGF21KO mice challenged with HFMCD.

Results

Significant increase of FGF15 production was found in the liver of the NASH-FGF21KO mice, however the increased FGF15 protein was unable to alleviate hepatic lipid accumulation. In contrast, the up-regulated hepatic FGFR4- $\beta$-klotho was found during NASH progression, as evident by hepatocyte injury/repair, fibrosis and potential malignant events, in the NASH-FGF21KO mice.

\section{Conclusion}

The increased FGF15 production in NASH-FGF21KO mice could not substitute for FGF21 to compensate its lipid metabolic benefits thereby to prevent NASH development. The up-regulated FGFR4/ $\beta$-klotho was coupled to cellular and molecular events which might associate to carcinogenic transformation.

\section{Background}

As the most severe form of non-alcoholic fatty liver disease (NAFLD), Nonalcoholic steatohepatitis (NASH) has been accepted to be a risk factor of hepatocellular carcinoma (HCC)[1]. NAFLD advances to the progressive form of NASH in about $44 \%$ of patients[2]. $\mathrm{HCC}$ has been recognized increasingly in NASH patients before the cirrhosis stage[3, 4]. The basis of NASH-related HCC carcinogenesis remains largely unknown; however, early treatment may determine long-term NASH prognosis[5]. Our previous studies showed that up-regulation of fibroblast growth factor (FGF)15/19 signaling and its receptors FGFR4/beta-klotho in NASH-HCC mice and in HCC patients[6, 7]. We also found that lack of FGF21 increased NASH severity and ensued pro-inflammatory signaling in the FGF21 knockout (FGF21KO) mice[8]. In a diabetes-HCC mouse model, we found that the hepatic FGF21 protein level was increased in elopment of HCC[9]. Our previous studies indicated that 
FGF21 played a key role in preventing the development of the major characteristics of NASH: steatosis, inflammation, and metabolic syndrome, however, the FGF15/19 mediated-FGFR4 signaling worsened $\mathrm{NASH}$ and even contributed to the NASH-HCC transition.

Fibroblast growth factors family composed of a group of structurally related polypeptides which involved in various biological processes including development, differentiation, neuronal functions, and metabolism[10]. There are three endocrine FGFs-FGF15/19, FGF21, and FGF23-identified in mouse/human, and human FGF19 is the orthologous gene of mouse FGF15[11]. FGF21 is predominantly produced by hepatocytes, while FGF15/19 is mostly secreted from the ileum but targeted to liver. Hepatic FGF21 elicits its metabolic benefits under the regulation of peroxisome proliferator-activated receptor a (PPARa), acting on the distal adipose tissue adipocytes, through the transmembrane receptor FGFR1coreceptor $\beta$-Klotho complex[12]. This major endocrine actions of FGF21 in terms of lipid metabolic benefits include control of lipolysis, clearance of excessive FFAs, enhancing mitochondrial oxidation and expenditure of the stored lipid energy, therefore negatively regulating hepatic or tissue steatosis, and adiposity[13-15]. FGF21, as an endocrine hormone, also takes part in the regulation of glucose and lipid metabolism[16], while pharmacological application has shown that FGF21 can be a promising and effective therapeutic agent for treating NASH, obesity and diabetes[17-19]. FGF15/FGF19 has been also reported to prevent NASH[20-22]. Although FGF15/19 upon the mitogenic and cytoprotective effects is critical in protection of hetaptocyte from lipid-mediated cellular stress and injury [20], the carcinogenetic role of FGF15/19/FGFR4 signaling has been well studied in various malignances, including breast cancer, gastric cancer, lung cancer, prostate cancer, nasopharyngeal carcinoma and liver cancer[23]. FGF15/19 on glucose metabolism and its crucial regulatory role in bile acid (BA) homeostasis have endorsed FGF15/19's metabolic benefits for whole body lipid metabolism[24]. However, it is not known whether FGF19 signaling in the liver is indispensable against hepatic lipid accumulation to substitute for FGF21 to compensate the metabolic benefits when FGF21 protein is compromised in liver.

In this study, early and advanced NASH models were established in FGF21KO mice fed with high fat methionine-choline deficient (HFMCD) diet to investigate FGF15/FGFR4 signaling during NASH development. We sought to determine whether FGF15/FGFR4 signaling could alleviate or aggravate NASH in FGF21KO mice challenged with HFMCD.

\section{Materials And Methods}

\section{Establishing NASH models}

FGF21 Knockout (FGF21KO) mice with C57 BL/6J background were generously granted by Dr. Steve Kliewer (University of Texas Southwestern Medical Center). Wild-type (WT) C57 BL/6J mice were obtained from Jackson Laboratory (Bar Harbor, ME). Six-weeks old male mice were fed with Rodent Diets, HFMCD (L-amino acid diet with $60 \mathrm{kcal} \%$ fat, 0.1\% methionine and no added choline, A06071302, Research Diets, Inc., New Brunswick, NJ) to induce NASH. Rodent Diet (CD, 10\% kcal\% fat, D12450B, 
respective diets were assigned randomly into the groups: WT-CD; WT-HFMCD; FGF21KO-CD; FGF21KOHFMCD. The mice were sacrificed at week 2 for early NASH model and 3 months for advanced NASH model according to previous report[25]. Body weight, liver weight and gross anatomy of liver lobes were determined and evaluated. At respective time points, animals were sacrificed to collect serum and hepatic tissues for further biochemical analysis. Alanine aminotransferase (ALT) was measured using an ALT infinity enzymatic assay kit (ThermoFisher Scientific Inc., Waltham, MA), while triglyceride (TG) was determined in serum and hepatic tissues using a mouse TG assay kit (Cayman Chemical Company, CA). The animal procedures were approved by the Institutional Animal Care and Use Committee of University of Louisville, which is certified by the American Association for Accreditation of Laboratory Animal Care.

\section{Gross anatomy, histopathological examination and NASH scoring}

The whole liver was isolated, weighted, and examined macroscopically for each animal. The harvested tissues were fixed in either $10 \%$ neutral phosphate buffered formalin for paraffin embedding or directly embedded in Optimal Cutting Temperature medium (OCT) and frozen by liquid nitrogen. The formalin fixed tissues were further embedded in paraffin and sectioned to a thickness of $5 \mu \mathrm{m}$ for histological and immunohistochemical examinations. To detect lipid accumulation in the liver tissues, Oil Red 0 staining for was performed in OCT-embedded tissue. Hematoxylin-and-eosin (H\&E) staining for histological evaluation was performed in paraffin-embedded frozen tissue and the images were reviewed and analyzed microscopically for determination of NASH. The Histological Scoring System for NASH is reported by the Pathology Subcommittee of the NASH Clinical Research Network[26]. This scoring system is calculated by the sum of scores of steatosis $(0-3)$, lobular inflammation $(0-3)$ and hepatocyte ballooning (0-2). The scoring is conducted as follows: Steatosis: $0,<5 \% ; 1,5-33 \% ; 2,>33 \% ; 3,>66$. Lobular Inflammation: 0, no foci; 1, <2 foci/200X; 2, 2-4 foci/200X; 3, > 4 foci/200X. Hepatocyte Ballooning: 0 , no balloon cells; $1,1-5$ balloon cells/200X; $2,>5$ balloon cells/200X.

\section{Immunohistochemical (IHC) analysis}

IHC staining (DAKO EnVisionTM + System Kit, DAKO Corporation, Carpinteria, CA) and dual-IHC staining (DoubleStain IHC Kit, Abcam, Cambridge, MA) was carried out on the paraffin-embedded tissues according to the manufacturer's instructions. was performed on the paraffin embedded tissue sections. For dual-IHC staining, in brief, endogenous peroxidase was blocked with $3 \%$ hydrogen peroxide, and then with $5 \%$ BSA for 30 min to block non-specific reaction. These tissue sections were incubated with the firstprimary antibodies (see antibody list in supplemental) over night. Tissue sections were incubated with AP-conjugated polymer (1: 300-400 dilutions with PBS) for 1 hour in room temperature, and then incubated with mixture of AP-substrate, AP-activator and AP-chromogen to develop pink color. Tissue sections were then incubated with the second-primary antibodies (see antibody list in supplemental Table 1) for 2 hours in room temperature. Tissue sections were incubated with HRP-conjugated polymer (1: 300-400 dilutions with PBS) for 1 hour in room temperature. Hematoxylin staining was performed before emerald-chromogen staining. Tissue sections and then incubated with emerald-chromogen to Loading [MathJax]/jax/output/CommonHTML/jax.js fuired with the Olympus $1 \times 51$ microscope (Olympus, 
Pittsburgh, PA) at 10x magnification using the Olympus DP72 digital camera and the length of scratchwound was measured via the cellSens Dimention imaging system. Computer image analysis was performed to acquire color images from the immunohistochemical staining and define a standard threshold of positive staining according to the software specification. The computer program then quantified the threshold area which represented the positive staining.

\section{Terminal deoxynucleotidyl transferase-mediated dUTP nick end labeling (TUNEL) assay}

Using an Apop-Tag Peroxidase In Situ Apoptosis Detection Kit (Chemicon, Billerica, CA), a TUNEL assay was performed, in brief, the tissue sections were treated with proteinase $\mathrm{K}(20 \mathrm{mg} / \mathrm{L})$ for $15 \mathrm{~min}$, and then incubated with terminal deoxynucleotidyl transferase (TdT) and digoxigenin-11-dUTP for 1 hour at $37^{\circ} \mathrm{C}$. Then, the anti-digoxigenin antibody conjugated with horseradish peroxidase (HRP) was applied and HRP substrate $\left(\mathrm{DAB}-\mathrm{H}_{2} \mathrm{O}_{2}\right)$ was applied to develop brow color for visualization. Apoptotic cells were quantitatively analyzed by counting the TUNEL positive cells in tissues for each section at $20 \mathrm{X}$ magnification. The apoptotic index was calculated based on the TUNEL positive cells per 100 cells.

\section{Western blot assay}

The protein levels in the tissue samples analyzed by Western blot as described previously [25]. In brief, electrophoresis was performed on $12 \%$ SDS-PAGE gel to separate proteins, and then the separated proteins were transferred to nitrocellulose membrane. The protein-loading membranes were incubated with the primary antibodies (see Table 1 antibody list in supplemental file) overnight at $4^{\circ} \mathrm{C}$ and then were incubated with secondary antibody for 1 hour at room temperature. The targeted protein complexes were then visualized using ECL kit (Amersham, Piscataway, NJ). The visualized protein bands were quantified by densitometry analysis.

\section{Real-Time RT-PCR (qPCR)}

Total RNA was extracted from tissues using the TRIzol reagent (Invitrogen). First-strand complimentary DNA (cDNA) was synthesized from total RNA, according to manufacturer's protocol of the cDNA transcription kit (Promega, Madison, WI, USA). Quantitative PCR was carried out using the ABI 7300 realtime PCR system (Applied Biosystems, Carlsbad, CA). The primers are listed in supplemental file Table 2. The expression of targeting mRNA was quantified and $\beta$-actin was used as an endogenous reference. Results were expressed as fold change in gene expression.

\section{Cell lines and in vitro study}

The cells for in vitro study include a mouse hepatic cell line, FL83B (ATCC® CRL-2390), human HCC cell lines, HepG2 (ATCC ${ }^{8}$ HB-8065) and Hep3B (ATCC ${ }^{8}$ HB-8064), and a human colorectal adenocarcinoma cell line, Caco-2 (ATCC $B$ HTB-37). The cells were cultured, FL83B cells in the F12K medium (ATCC), HepG2 and Hep3B cells in DMEM medium, and Caco-2 cells in EMEM medium respectively, with $10-15 \%$ fetal bovine serum. To study the effects of FFA on the cell lines regarding the FGF15/FGFR4 signaling, Loading [MathJax]/jax/output/CommonHTML/jax.js hbinant mouse (rm) FGF-15 protein (Abcam, ab125734), 
recombinant human (rh) FGF21 protein (Abcam, ab217404) and BLU9931 (MedChemExpress, HY-12823), and rhFGF19 (R\&D, 969-FG) were used to treat the cells. PA media was made by dissolving $2 \%$ bovine serum albumin (BSA, US Biologicals, A1311) in cell culture medium and the 100uM PA working solution was prepared from a high concentration $(20 \mathrm{mM})$ stock PA solution made by $\mathrm{dH} 2 \mathrm{O}$ heated to $70^{\circ} \mathrm{C}$. Based on the previous reports, rmFGF15 protein was applied at $100 \mathrm{ng} / \mathrm{ml}[27]$, rhFGF21 protein was applied at $1.1 \mu \mathrm{g} / \mathrm{ml}[28]$, BLU9931 was applied at the concentration of 100nM[29], for up to 24 hours. rhFGF19 was applied at the concentration of $100 \mathrm{ng} / \mathrm{ml}[27]$, for up to 24 hours. Caco-2 cells were cocultured with HepG2 or Hep3B cells for up to 24 hours to study the FGFR4 signaling based cross-talk between enterocyte and hepatocytes. Immunofluorescent staining was performed in the cells using FITCconjugated or PE-conjugated IgG (see Table 1 antibodies listed in supplemental file) and DAPI for counterstaining.

\section{Statistical analysis}

Data being collected from the repeated experiments were presented as mean \pm SD. Statistical analysis was performed by using SPSS V.17.0. Statistical significance for study groups was determined by ANOVA. The post hoc Tukey's test was used for analysis of any differences between groups. Group difference was considered as statistical significance for $p<0.05(*), p<0.01(* *)$.

\section{Result}

\section{Lack of FGF21 worsens the HFMCD-induced NASH in mice}

Based on the previous reports[25], we established an early NSAH model in FGF21KO mice with 2-weeks HFMCD feeding. The gross appearance of NASH liver, unlike the normal liver lobes with red-velvet color, showed diffusely pale-yellow-tan color lobes and increased liver weight along with increased body weight and serum ALT level in FGF21KO-HFMCD mice (Fig. 1S). Steatohepatitis was defined in mice, as evident by the histology and confirmed by NAFLD Active Score (NAS) system which was accepted as a surrogate of histologic diagnosis of NASH. In a previous study of NAFLD patients, the score of $\geq 5$ was strongly correlated with the pathological diagnosis of "definite NASH", whereas the score $\leq 3$ was designated "not NASH"[26]. All the mice with 2-weeks HFMCD feeding were found with NAS of $>5$ and diagnosed as steatohepatitis. The highest NAS was found in the group of FGF21KO-HFMCD mice, with statistical significance compared to all other groups (Fig. 1A). Consistent to NAS, highest protein level of FGF15 by IHC was found in the group of FGF21KO-HFMCD mice, with statistical significance compared to all other groups (Fig. 1B). Western blot analysis confirmed the IHC results (Fig. 1C). The results indicated that FGF15 protein was significantly increased the liver tissues of FGF21 KO mice, however the increased FGF15 protein did not show protection against the HFMCD induced steatohepatitis in FGF21KO mice.

\section{Ileum FGF15 upregulates hepatic FGFR4- $\beta$ klotho in FGF21KO-HFMCD mice}


FGF15/19 is an enterokine and expresses abundantly in the distal small intestine. Upon bile acids stimulation, the enterocyte secreted FGF15/19 was released to the portal blood and reached liver, binding to FGFR4 and co-receptor $\beta$-klotho of hepatocytes and triggering a signaling cascade involving hepatic bile acid, lipid and glucose metabolism[30, 31]. Pphysiological expression of FGF15/19 in hepatocytes is not detected[32], but pathological FGF19 expression was detected in liver tissues of patients with hepatitis $C$ virus-related cirrhosis or biliary cirrhosis[33]. We further investigated the resource of FGF15 production and hepatic FGFR4/ $\beta$-klotho expressions. The results indicated that significantly increased mRNA expression in the intestinal tissues and increased serum FGF15 protein levels were found in FGF21KO-HFMCD mice, compared to all other groups(Fig. 2A-B). However, the mRNA of FGF15 was not detectable in hepatic tissues of all groups of mice (data not shown). A dual IHC staining for FGFR4 and $\beta$ klotho was performed in the liver tissues. The results indicated that FGFR4 and $\beta$-klotho were coexpressed in the hepatocytes, while FGFR4/ $\beta$-klotho expressions were significantly up-regulated in the FGF21KO-HFMCD mice, compared to all other groups (Fig. 2C). qPCR and Western blot analysis of liver tissues further confirmed the IHC results (Fig. 2D). The results indicated that the hepatic FGFR4/ $\beta$-klotho signaling was significantly upregulated in the FGF21KO-HFMCD mice, implying that severity of NASH might associate to the aberrant FGFR4/ $\beta$-klotho signaling.

\section{FGF15 is unable to alleviate steatosis but up-regulates FGFR4 in the FGF21KD hepatocytes}

The binding of FGF15/19 to FGFR4/ $\beta$-Klotho not only suppresses BA synthesis in hepatocytes via inhibition of cholesterol 7a-hydroxylase 1 (CYP7A1), the rate-limiting step for bile acid synthesis[34], but also activates signaling cascades leading to increased insulin sensitivity, improved glucose metabolism, as well as reduction of body weight[35]. However, it is unknown whether FGF15 can directly alleviate steatosis in hepatocytes. Therefore, we further investigated the effect of FGF15 on steatosis using FL83B cells, a benign mouse cell line of hepatocyte. To mimic the FGF21KO mice, a shRNA assay to was performed to knockdown (KD) FGF21 gene in the FL83B cells. Both FGF21KD (21KD) FL83B cells and the shRNA control (shCT) FL83B cells were challenged with palmitic acid (PA) and treated with rmFGF15 or rhFGF21. Lipid accumulation in hepatocytes were detected by Oil-red $O$ staining. The result indicated that PA challenging significantly up-regulated lipid accumulation in both FGF21KD FL83B cells and shCTFL83B cells, while treatment with rhFGF21 attenuated the up-regulated lipid accumulation. Unlike FGF21, FGF15 treatment did not show the attenuation of up-regulated lipid accumulation in the shRNA control FL83B cells. In contrast, highest level of lipid accumulation was found in the FGF21KD-FL83B cells with FGF15 treatment (Fig. 3A). As a regulatory function of hepatic FGFR4 to promote hepatic TG accumulation has been reported previously[36], we further investigated the FGFR4 levels in hepatocytes. FGF15 treatment significantly up-regulated FGFR4 expression in both shCT-FL83B and FGF21KD-FL83B cells challenged with PA, however, FGF21 treatment did not show up-regulation of FGFR4 levels (Fig. 3B). We further investigated the major enzymes for de novo synthesis, FA esterification and FA transport. Upregulated FASN, Acc1 and Acc2 (de novo synthesis), Dgat1 and Acat1(esterification), and Mttp, Apoa1 and CD36 (transport) were found in and FGF21 KD-FL83B cells challenged with PA (Fig. 3C), implying that Loading [MathJax]/jax/output/CommonHTML/jax.js ld be either from de novo synthesis or FFAs uptake. Taken 
together, the bioactivities of FGF15 on hepatocytes, instead of alleviating lipid accumulation, was shown to up-regulate FGFR4, while compromised FGF21 worsened steatosis in hepatocytes.

\section{NASH progression is associated to the up-regulated FGFR4 levels in FGF21KO mice}

Although the FGFR4 mediated-benign hepatic TG storage might provide protection on hepatocytes, continuously up-regulated FGFR4 signaling could play a deleterious role contributing to cell proliferation and progression of cancers[23]. According to this hypothesis, we further determined the levels of FGF15 as well its receptors FGFR4/ $\beta$-klotho (KLB) in an advanced NSAH model of FGF21KO mice with HFMCD feeding for 3 months. Unlike the early stage NASH model, the gross appearance of in advanced NASH liver showed diffusely pale-yellow color lobes and increased liver weight along with increased body weight and serum TG level in FGF21KO-HFMCD mice (Figure S2). Of note, when we analyzed the morphological changes of NASH liver, multiple nodules were detected microscopically in hepatic parenchyma of the liver tissues from FGF21KO + HFMCD mice (Fig. 4A). Histological changes showed severe steatohepatitis, as evident by significantly increased NAS, multiple nodules in hepatic parenchyma, significantly increased for Kupffer cells/macrophages detected by $\mathrm{IHC}$ for $\mathrm{F} 4 / 80$, and significantly increased serum ALT level in the FGF21KO-HFMCD mice compared to all other groups (Fig. 4A). As expected, significantly increased protein levels of FGF15 and FGFR4/ $\beta$-klotho and were detected by Western blot analysis in the liver of FGF21KO-HFMCD mice compared to all other groups (Fig. 4B). Overexpressions of FGFR4 and $\beta$-klotho in the liver of FGF21KO-HFMCD mice with advanced NASH were confirmed by IHC and qPCR (Figure S3). Taken together, continuously up-regulated FGFR4 expression in advanced NASH should call attention because hyperactivation of FGFR4 by FGF19 was reported in colon cancer and HCC[37]. However, FGF15/19 was also reported to down-regulate FGFR4 and $\beta$-klotho[27]. Therefore, we further studied the FGFR4 signaling in advanced NASH model in regard of the malignant potential.

\section{Up-regulated FGFR4 signaling is coupled to fibrotic and malignant events in FGF21KO mice}

Cirrhosis and HCC have become the major liver-related clinical endpoints in NASH, while fibrosis progression and malignant transformation are driven by repetitive damages/repairs via apoptosis and cell proliferation[2]. To study fibrosis and the cellular events, we performed Sirius Red staining for fibrosis, IHC of PCNA for proliferation, and TUNEL assay for apoptosis in the liver tissues from the advanced NASH model with HFMCD feeding for 3 months. Significantly increased level of collagen fiber, as showing the red color by Sirius Red staining, was found in FGF21KO-HFMCD mice compared to all other groups (Fig. 5A). Consistent to Sirius Red staining, significantly increased levels of apoptosis and cell proliferation, indicated by the indexes of positive apoptotic cells and positive PCNA cells, were also found in FGF21KO-HFMCD mice compared to all other groups (Fig. 5A). To evaluate the potential malignant phenotype, the epithelial-mesenchymal transition (EMT) event was investigated by a dual IHC staining for E-cadherin and vimentin in the liver tissues. The results indicated that E-cadherin expression was Loading [MathJax]/jax/output/CommonHTML/jax.js 
significantly down-regulated but vimentin expression was significantly up-regulated in the FGF21KOHFMCD mice, compared to all other groups (Fig. 5A). Western blot analysis was further performed in the liver tissues and the results indicated that significant increases of cyclin D1 and cleaved caspase-3 but significant decrease of BCL-2 was found in FGF21KO-HFMCD mice, compared to all other groups (Fig. 5B). Taken together, increased fibrosis and deleterious molecular and cellular events were found in in FGF21KO-HFMCD mice which with advanced NASH, while up-regulated FGFR4 expression was coupled to these molecular and cellular events.

Blockage of FGFR4 attenuates proliferation and EMT in hepatocytes and HCC cells.

BLU9931 is a highly selective, covalent, small-molecule inhibitor that specifically targets FGFR4 via binding within the ATP-binding pocket of FGFR4 to form a covalent bond with Cys552, resulting in >95\% proteolysis[29]. We used BLU9931 to study whether blocking FGFR4 could inhibit the cell proliferation and EMT event. With BLU9931 treatment, significantly decreased protein level of FGFR4 was found in FGF21KD FL83B cells either with PA challenging or without. Blockage of FGFR4 signaling by BLU9931 significant decreased cyclin D1 in FGF21KD FL83B cells either with PA challenging or without (Fig. 6A). Consistently, blockage of FGFR4 signaling alleviated significantly the EMT in FGF21 KD FL83B cells either with PA challenging or without (Fig. 6B). In addition, we performed a co-cultured study using human hepatocyte cell lines (HepG2 and Hep3B) and an enterocyte cell line (Caco-2) to mimic the enterohepatic circulation in regards of the FGF19/FGFR4 signaling. When Caco-2 cells co-cultured with either HepG2 or Hep3B, significantly increased levels of cyclin D1 was detected in both HepG2 cells and Hep3B cells. When co-cultured with Caco-2 cells, cyclin D1 was also significantly up-regulated in HepG2 cells and Hep3B cells. BLU9931 treatment attenuated the up-regulated cyclin D1 levels in both HepG2 cells and Hep3B cells co-cultured with Caco-2 cells (Fig. 6C). These results demonstrated that blockage of FGFR4 could attenuate the deleterious cellular and molecular events which could be associated to NASH and HCC progression.

\section{Discussion}

As a liver safeguard[38], FGF21 was widely reported to alleviate hepatic fat stress via directly reducing hepatic lipid accumulation in an insulin-independent manner[39]. Similar to FGF21, FGF15/19 was also reported to function in controlling whole body lipid metabolism through increasing energy expenditure, FA oxidation, and decreasing de-novo lipogenesis[20]. However, it was unknown whether FGF15/19 could directly reduce hepatic lipid accumulation, especially when FGF21 was not function well such as FGF21 resistance in obesity[40]. In this study, we investigated the FGF15/FGFR4 signaling in FGF21KO mice during NASH development. Significant increase of FGF15 production was found in the NASH-FGF21KO mice, however the increased FGF15 protein was unable to alleviate hepatic lipid accumulation. In contrast, the up-regulated FGFR4 expression was coupled to fibrosis, hepatocyte injury/repair, and potential malignant events in the FGF21KO mice with advanced NASH. 
Both FGF15 and FGF19 function as a negative feedback signal shutting down BA synthesis when BAs levels are high in the intestinal mucosa. Regarding the bioactivity on NASH, studies either from transgenic mice or treatment with FGF19 protein have shown that FGF19 alleviates lipid accumulation in the liver and thereby prevents $\mathrm{NASH}[20,41,42]$. However, the effect of FGF15 on NASH is reportedly contradictory. For example, a study reported that the FGF15 knockout mice fed a HFD worsened steatosis[20] but another study that also fed with HFD to the FGF15 knockout mice did not show worsened steatosis severity[43]. The protein discrepancy between FGF15 and FGF19 has been identified previously, in which they share only $50 \%$ sequence homology $[30,44]$ even though they are orthologs and both are considered as endocrine FGFs because they cannot bind heparin sulfate and thus escape from extracellular matrix. Studies of chimeric immunodepressed mice which transplanted with human hepatocytes further emphasized the bioactive discrepancy between FGF15 and FGF19, in which FGF19 administration reversed the enlarged bile acid pool size[45], but significantly elevated FGF15 was unable to suppress hepatic CYP7A1 expression[33]. The increased hepatic BAs level not only induces liver injury[46] but also plays an important role in the regulation of hepatocytes regeneration[47], contributing to NASH development through repetitive injury/repair. BAs reabsorbed in the intestine can increase the FGFR4/ $\beta$ klotho levels in hepatocytes for subsequent FGF15/FGFR4 signaling in liver[48], while hepatic FGFR4 is reported to promote hepatic lipid accumulation by either HFD or healthy diet [24] [36]. In our study, the significant increased FGF15 in the NASH-FGF21KO mice was unable to alleviate hepatic lipid accumulation, while up-regulated FGFR4 expression was coupled to fibrosis and deleterious molecular and cellular events in advanced NASH. This might be explained by, 1) although FGF15 protein was very high in liver, it was unable to suppress hepatic CYP7A1 expression[33] for BA synthesis and BAs could induce liver injury and cell death[46]; 2) the BAs mediated up-regulation of FGFR4 in hepatocytes [48] could not only promote hepatic lipid accumulation[24] [36] but also induce regeneration[47], causing repetitive injury/repair in liver; and 3) lack of FGF21 further worsened steatosis and the NASH progression. Our findings indicate a dramatically different roles of FGF15 and FGFR4- $\beta$-klotho during $\mathrm{NASH}$ development in FGF21KO mice.

The liver generally maintains an appropriate size in adults. Loss of hepatocytes because of repetitive injury allows the liver to begin growing which is accepted as a fundamental mechanism(s) in cancer biology. Emerging studies have shown that FGFR4 play important roles in liver regeneration and carcinogenesis. For post-hepatectomy liver regeneration, FGFR4 was found to complex with $\beta$-klotho on hepatocyte membrane, upon FGF19/FGF15 binding, to initiate regeneration and orchestrate BAs acid detoxification as a protective mechanism in concurrence with the proliferative signaling[49]. In HCC, FGF19 promotes the HCC cell growth and inhibits apoptosis via activating a FGFR4-GSK3 $\beta$-Nrf2 signaling cascade[50]. The aberrant FGFR4 signaling has been reported to be an oncogenic-driver pathway for HCC development[51]. In our studies, up-regulated FGF15 and FGFR4/ $\beta$-klotho were found to coupled fibrosis and deleterious cellular events during the NASH development in FGF21KO mice. These findings are in accordance with our previous studies in HFD- or diabetes- induced NASH mice[6, 8]. This study is mainly designed to investigate FGF15/FGFR4 expression during the NASH development in FGF21KO mice. The mainr limitation of thic ctudv ic lark of FfF 15KO/overexpressing mice to elucidate the molecular Loading [MathJax]/jax/output/CommonHTML/jax.js

Page $10 / 23$ 
mechanisms of FGF15/FGFR4 signaling pathway contributing to NASH progression and HCC development. Further studies are needed to determine the roles of FGF15/FGFR4/ $\beta$-klotho as well as the downstream signaling during NASH progression. The FGFR4/ $\beta$-klotho/BAs associated carcinogenesis via Gut-Liver axis is also an important issues and needs to further study in NASH-HCC transition models.

\section{Conclusion}

The increased FGF15 production in NASH-FGF21KO mice could not substitute for FGF21 to compensate its lipid metabolic benefits thereby to prevent NASH development. The up-regulated FGFR4/ $\beta$-klotho was coupled to cellular and molecular events which might associate to carcinogenic transformation. This study provided a new insight into FGF15 and FGFR4/ $\beta$-klotho during NASH development and the potential pharmacological application to target FGFR4 for treatment in advanced NASH.

\section{Abbreviations}

FGF21: Fibroblast growth factor21; FGF15/19: Fibroblast growth factor15/19; NASH: Nonalcoholic steatohepatitis; HFMCD: High fat methionine-choline deficient; FFA: free fatty acid; KO: knockout; NAFLD: Non-alcoholic fatty liver disease; HCC: Hepatocellular carcinoma; ALT: Alanine aminotransferase; TG: Triglyceride; H\&E: Hematoxylin and eosin; NAS: NAFLD activity score; shCT: shRNA Control; PA: Palmic acid.

\section{Declarations}

\section{Ethics approval and consent to participate}

The animal procedures were approved by the Institutional Animal Care and Use Committee of University of Louisville, which is certified by the American Association for Accreditation of Laboratory Animal Care.

\section{Consent for publication}

Not applicable

\section{Availability of data and material}

Not applicable

\section{Funding}

Research reported in this publication was supported partly by an Institutional Development Award (IDeA) from the NIGMS of the National Institutes of Health under grant number P20GM113226. The content is solely the responsibility of the authors and does not necessarily represent the official views of the National Institutes of Health. 


\section{Competing interests}

The authors declare that they have no competing interests

\section{Authors' contributions}

Youxi Yu worked for the animal models, IHC and western blot, data analysis and manuscript draft writing. Xiaoju shi, Qianqian Zheng, Min Tan and Wei Guo worked for RT-PCR and serum biomarkers measurements. Xingkai, Guoyue Lv, and Ping Zhang contributed to clinical consultant and experimental design and experimental design. Robert C. Martin contributed to the experimental design, clinical consultant and manuscript English checking. Yan Li contributed to data analysis and manuscript writing and editing.

\section{Acknowledgements}

N/A

\section{References}

[1] Marengo A, Rosso C and Bugianesi E. Liver Cancer: Connections with Obesity, Fatty Liver, and Cirrhosis. Annu Rev Med 2016; 67: 103-117.

[2] McPherson S, Hardy T, Henderson E, Burt AD, Day CP and Anstee QM. Evidence of NAFLD progression from steatosis to fibrosing-steatohepatitis using paired biopsies: implications for prognosis and clinical management. J Hepatol 2015; 62: 1148-1155.

[3] Leung C, Yeoh SW, Patrick D, Ket S, Marion K, Gow P and Angus PW. Characteristics of hepatocellular carcinoma in cirrhotic and non-cirrhotic non-alcoholic fatty liver disease. World J Gastroenterol 2015; 21 : 1189-1196.

[4] Guzman G, Brunt EM, Petrovic LM, Chejfec G, Layden TJ and Cotler SJ. Does nonalcoholic fatty liver disease predispose patients to hepatocellular carcinoma in the absence of cirrhosis? Arch Pathol Lab Med 2008; 132: 1761-1766.

[5] Tilg $\mathrm{H}$ and Moschen A. Update on nonalcoholic fatty liver disease: genes involved in nonalcoholic fatty liver disease and associated inflammation. Curr Opin Clin Nutr Metab Care 2010; 13: 391-396.

[6] Cui G, Martin RC, Jin H, Liu X, Pandit H, Zhao H, Cai L, Zhang P, Li W and Li Y. Up-regulation of FGF15/19 signaling promotes hepatocellular carcinoma in the background of fatty liver. J Exp Clin Cancer Res 2018; 37: 136.

[7] Cui G, Martin RC, Liu X, Zheng Q, Pandit H, Zhang P, Li W and Li Y. Serological biomarkers associate ultrasound characteristics of steatohepatitis in mice with liver cancer. Nutr Metab (Lond) 2018; 15: 71. 
[8] Liu X, Zhang P, Martin RC, Cui G, Wang G, Tan Y, Cai L, Lv G and Li Y. Lack of fibroblast growth factor 21 accelerates metabolic liver injury characterized by steatohepatities in mice. Am J Cancer Res 2016; 6: 1011-1025.

[9] Zhang Q, Li Y, Liang T, Lu X, Liu X, Zhang C, Jiang X, Martin RC, Cheng M and Cai L. Loss of FGF21 in diabetic mouse during hepatocellular carcinogenetic transformation. Am J Cancer Res 2015; 5: 17621774.

[10] Beenken A and Mohammadi M. The FGF family: biology, pathophysiology and therapy. Nat Rev Drug Discov 2009; 8: 235-253.

[11] Owen BM, Mangelsdorf DJ and Kliewer SA. Tissue-specific actions of the metabolic hormones FGF15/19 and FGF21. Trends Endocrinol Metab 2015; 26: 22-29.

[12] Fisher FM and Maratos-Flier E. Understanding the Physiology of FGF21. Annu Rev Physiol 2016; 78: 223-241.

[13] Inagaki T, Dutchak P, Zhao G, Ding X, Gautron L, Parameswara V, Li Y, Goetz R, Mohammadi M, Esser V, Elmquist JK, Gerard RD, Burgess SC, Hammer RE, Mangelsdorf DJ and Kliewer SA. Endocrine regulation of the fasting response by PPARalpha-mediated induction of fibroblast growth factor 21. Cell Metab 2007; 5: 415-425.

[14] Adams AC, Yang C, Coskun T, Cheng CC, Gimeno RE, Luo Y and Kharitonenkov A. The breadth of FGF21's metabolic actions are governed by FGFR1 in adipose tissue. Mol.Metab. 2012; 2: 31-37.

[15] Ye M, Lu W, Wang X, Wang C, Abbruzzese JL, Liang G, Li X and Luo Y. FGF21-FGFR1 Coordinates Phospholipid Homeostasis, Lipid Droplet Function, and ER Stress in Obesity. Endocrinology 2016; 157: 4754-4769.

[16] Guan D, Zhao L, Chen D, Yu B and Yu J. Regulation of fibroblast growth factor 15/19 and 21 on metabolism: in the fed or fasted state. J Transl Med 2016; 14: 63.

[17] Gaich G, Chien J, Fu HD, Kharitonenkov A and Moller D. Effects of an FGF21 Analog in Patients With Type 2 Diabetes. Diabetes 2013; 62: A28-A28.

[18] Gaich G, Chien JY, Fu H, Glass LC, Deeg MA, Holland WL, Kharitonenkov A, Bumol T, Schilske HK and Moller DE. The effects of LY2405319, an FGF21 analog, in obese human subjects with type 2 diabetes. Cell Metab. 2013; 18: 333-340.

[19] Lee JH, Kang YE, Chang JY, Park KC, Kim HW, Kim JT, Kim HJ, Yi HS, Shong M, Chung HK and Kim KS. An engineered FGF21 variant, LY2405319, can prevent non-alcoholic steatohepatitis by enhancing hepatic mitochondrial function. Am J Transl Res 2016; 8: 4750-4763. 
[20] Alvarez-Sola G, Uriarte I, Latasa MU, Fernandez-Barrena MG, Urtasun R, Elizalde M, Barcena-Varela M, Jimenez M, Chang HC, Barbero R, Catalan V, Rodriguez A, Fruhbeck G, Gallego-Escuredo JM, GavaldaNavarro A, Villarroya F, Rodriguez-Ortigosa CM, Corrales FJ, Prieto J, Berraondo P, Berasain C and Avila MA. Fibroblast growth factor 15/19 (FGF15/19) protects from diet-induced hepatic steatosis: development of an FGF19-based chimeric molecule to promote fatty liver regeneration. Gut 2017; 66: 1818-1828.

[21] Harrison SA, Rinella ME, Abdelmalek MF, Trotter JF, Paredes AH, Arnold HL, Kugelmas M, Bashir MR, Jaros MJ, Ling L, Rossi SJ, DePaoli AM and Loomba R. NGM282 for treatment of non-alcoholic steatohepatitis: a multicentre, randomised, double-blind, placebo-controlled, phase 2 trial. Lancet 2018; 391: 1174-1185.

[22] Valenti L and Nobili V. NGM282: a step forward in the nonalcoholic steatohepatitis treatment landscape? Hepatobiliary Surg Nutr 2018; 7: 484-486.

[23] Lin BC and Desnoyers LR. FGF19 and cancer. Adv Exp Med Biol 2012; 728: 183-194.

[24] Huang X, Yang C, Luo Y, Jin C, Wang F and McKeehan WL. FGFR4 prevents hyperlipidemia and insulin resistance but underlies high-fat diet induced fatty liver. Diabetes 2007; 56: 2501-2510.

[25] Stephenson K, Kennedy L, Hargrove L, Demieville J, Thomson J, Alpini G and Francis H. Updates on Dietary Models of Nonalcoholic Fatty Liver Disease: Current Studies and Insights. Gene Expr 2018; 18: 517.

[26] Brunt EM, Kleiner DE, Wilson LA, Belt P, Neuschwander-Tetri BA and Network NCR. Nonalcoholic fatty liver disease (NAFLD) activity score and the histopathologic diagnosis in NAFLD: distinct clinicopathologic meanings. Hepatology 2011; 53: 810-820.

[27] Li S, Hsu DD, Li B, Luo X, Alderson N, Qiao L, Ma L, Zhu HH, He Z, Suino-Powell K, Ji K, Li J, Shao J, $\mathrm{Xu} \mathrm{HE}$, Li T and Feng GS. Cytoplasmic tyrosine phosphatase Shp2 coordinates hepatic regulation of bile acid and FGF15/19 signaling to repress bile acid synthesis. Cell Metab 2014; 20: 320-332.

[28] Al-Aqil FA, Monte MJ, Peleteiro-Vigil A, Briz O, Rosales R, Gonzalez R, Aranda CJ, Ocon B, Uriarte I, de Medina FS, Martinez-Augustin O, Avila MA, Marin JJG and Romero MR. Interaction of glucocorticoids with FXR/FGF19/FGF21-mediated ileum-liver crosstalk. Biochim Biophys Acta Mol Basis Dis 2018; 1864: 2927-2937.

[29] Hagel M, Miduturu C, Sheets M, Rubin N, Weng W, Stransky N, Bifulco N, Kim JL, Hodous B, Brooijmans N, Shutes A, Winter C, Lengauer C, Kohl NE and Guzi T. First Selective Small Molecule Inhibitor of FGFR4 for the Treatment of Hepatocellular Carcinomas with an Activated FGFR4 Signaling Pathway. Cancer Discov 2015; 5: 424-437. 
[30] Xie MH, Holcomb I, Deuel B, Dowd P, Huang A, Vagts A, Foster J, Liang J, Brush J, Gu Q, Hillan K, Goddard A and Gurney AL. FGF-19, a novel fibroblast growth factor with unique specificity for FGFR4. Cytokine 1999; 11: 729-735.

[31] Fon Tacer K, Bookout AL, Ding X, Kurosu H, John GB, Wang L, Goetz R, Mohammadi M, Kuro-o M, Mangelsdorf DJ and Kliewer SA. Research resource: Comprehensive expression atlas of the fibroblast growth factor system in adult mouse. Mol Endocrinol 2010; 24: 2050-2064.

[32] Inagaki T, Choi M, Moschetta A, Peng L, Cummins CL, McDonald JG, Luo G, Jones SA, Goodwin B, Richardson JA, Gerard RD, Repa JJ, Mangelsdorf DJ and Kliewer SA. Fibroblast growth factor 15 functions as an enterohepatic signal to regulate bile acid homeostasis. Cell Metab 2005; 2: 217-225.

[33] Naugler WE, Tarlow BD, Fedorov LM, Taylor M, Pelz C, Li B, Darnell J and Grompe M. Fibroblast Growth Factor Signaling Controls Liver Size in Mice With Humanized Livers. Gastroenterology 2015; 149 : 728-740 e715.

[34] You M, Zhou Z, Daniels M and Jogasuria A. Endocrine Adiponectin-FGF15/19 Axis in Ethanol-Induced Inflammation and Alcoholic Liver Injury. Gene Expr 2018; 18: 103-113.

[35] Ge H, Zhang J, Gong Y, Gupte J, Ye J, Weiszmann J, Samayoa K, Coberly S, Gardner J, Wang H, Corbin T, Chui D, Baribault H and Li Y. Fibroblast growth factor receptor 4 (FGFR4) deficiency improves insulin resistance and glucose metabolism under diet-induced obesity conditions. J Biol Chem 2014; 289 : 30470-30480.

[36] Lutz SZ, Hennige AM, Peter A, Kovarova M, Totsikas C, Machann J, Krober SM, Sperl B, Schleicher E, Schick F, Heni M, Ullrich A, Haring HU and Stefan N. The Gly385(388)Arg Polymorphism of the FGFR4 Receptor Regulates Hepatic Lipogenesis Under Healthy Diet. J Clin Endocrinol Metab 2019; 104: 20412053.

[37] Liu Y, Cao M, Cai Y, Li X, Zhao C and Cui R. Dissecting the Role of the FGF19-FGFR4 Signaling Pathway in Cancer Development and Progression. Front Cell Dev Biol 2020; 8: 95.

[38] Cariello M and Moschetta A. Fibroblast growth factor 21: a new liver safeguard. Hepatology. 2014; 60: 792-794.

[39] Byun S, Seok S, Kim YC, Zhang Y, Yau P, Iwamori N, Xu HE, Ma J, Kemper B and Kemper JK. Fastinginduced FGF21 signaling activates hepatic autophagy and lipid degradation via JMJD3 histone demethylase. Nat Commun 2020; 11: 807.

[40] Fisher FM, Chui PC, Antonellis PJ, Bina HA, Kharitonenkov A, Flier JS and Maratos-Flier E. Obesity is a fibroblast growth factor 21 (FGF21)-resistant state. Diabetes 2010; 59: 2781-2789.

[41] Tomlinson E, Fu L, John L, Hultgren B, Huang X, Renz M, Stephan JP, Tsai SP, Powell-Braxton L, Loading [MathJax]/jax/output/CommonHTML/jax.js :xpressing human fibroblast growth factor-19 display 
increased metabolic rate and decreased adiposity. Endocrinology 2002; 143: 1741-1747.

[42] Zhou M, Learned RM, Rossi SJ, DePaoli AM, Tian H and Ling L. Engineered FGF19 eliminates bile acid toxicity and lipotoxicity leading to resolution of steatohepatitis and fibrosis in mice. Hepatol Commun 2017; 1: 1024-1042.

[43] Schumacher JD, Kong B, Pan Y, Zhan L, Sun R, Aa J, Rizzolo D, Richardson JR, Chen A, Goedken M, Aleksunes LM, Laskin DL and Guo GL. The effect of fibroblast growth factor 15 deficiency on the development of high fat diet induced non-alcoholic steatohepatitis. Toxicol Appl Pharmacol 2017; 330: 18.

[44] Nishimura T, Utsunomiya $Y$, Hoshikawa M, Ohuchi H and Itoh N. Structure and expression of a novel human FGF, FGF-19, expressed in the fetal brain. Biochim Biophys Acta 1999; 1444: 148-151.

[45] Ellis EC, Naugler WE, Parini P, Mork LM, Jorns C, Zemack H, Sandblom AL, Bjorkhem I, Ericzon BG, Wilson EM, Strom SC and Grompe M. Mice with chimeric livers are an improved model for human lipoprotein metabolism. PLoS One 2013; 8: e78550.

[46] Meadows V, Kennedy L, Kundu D, Alpini G and Francis H. Bile Acid Receptor Therapeutics Effects on Chronic Liver Diseases. Front Med (Lausanne) 2020; 7: 15.

[47] Alvarez-Sola G, Uriarte I, Latasa MU, Jimenez M, Barcena-Varela M, Santamaria E, Urtasun R, Rodriguez-Ortigosa C, Prieto J, Berraondo P, Fernandez-Barrena MG, Berasain C and Avila MA. Bile acids, FGF15/19 and liver regeneration: From mechanisms to clinical applications. Biochim Biophys Acta Mol Basis Dis 2018; 1864: 1326-1334.

[48] Fu T, Kim YC, Byun S, Kim DH, Seok S, Suino-Powell K, Xu HE, Kemper B and Kemper JK. FXR Primes the Liver for Intestinal FGF15 Signaling by Transient Induction of beta-Klotho. Mol Endocrinol 2016; 30: 92-103.

[49] de Haan L, van der Lely SJ, Warps AK, Hofsink Q, Olthof PB, de Keijzer MJ, Lionarons DA, MendesDias L, Bruinsma BG, Uygun K, Jaeschke H, Farrell GC, Teoh N, van Golen RF, Li T and Heger M. Posthepatectomy liver regeneration in the context of bile acid homeostasis and the gut-liver signaling axis. $J$ Clin Transl Res 2018; 4: 1-46.

[50] Teng Y, Zhao H, Gao L, Zhang W, Shull AY and Shay C. FGF19 Protects Hepatocellular Carcinoma Cells against Endoplasmic Reticulum Stress via Activation of FGFR4-GSK3beta-Nrf2 Signaling. Cancer Res 2017; 77: 6215-6225.

[51] Raja A, Park I, Haq F and Ahn SM. FGF19-FGFR4 Signaling in Hepatocellular Carcinoma. Cells 2019; 8:

\section{Einurace}

Loading [MathJax]/jax/output/CommonHTML/jax.js 

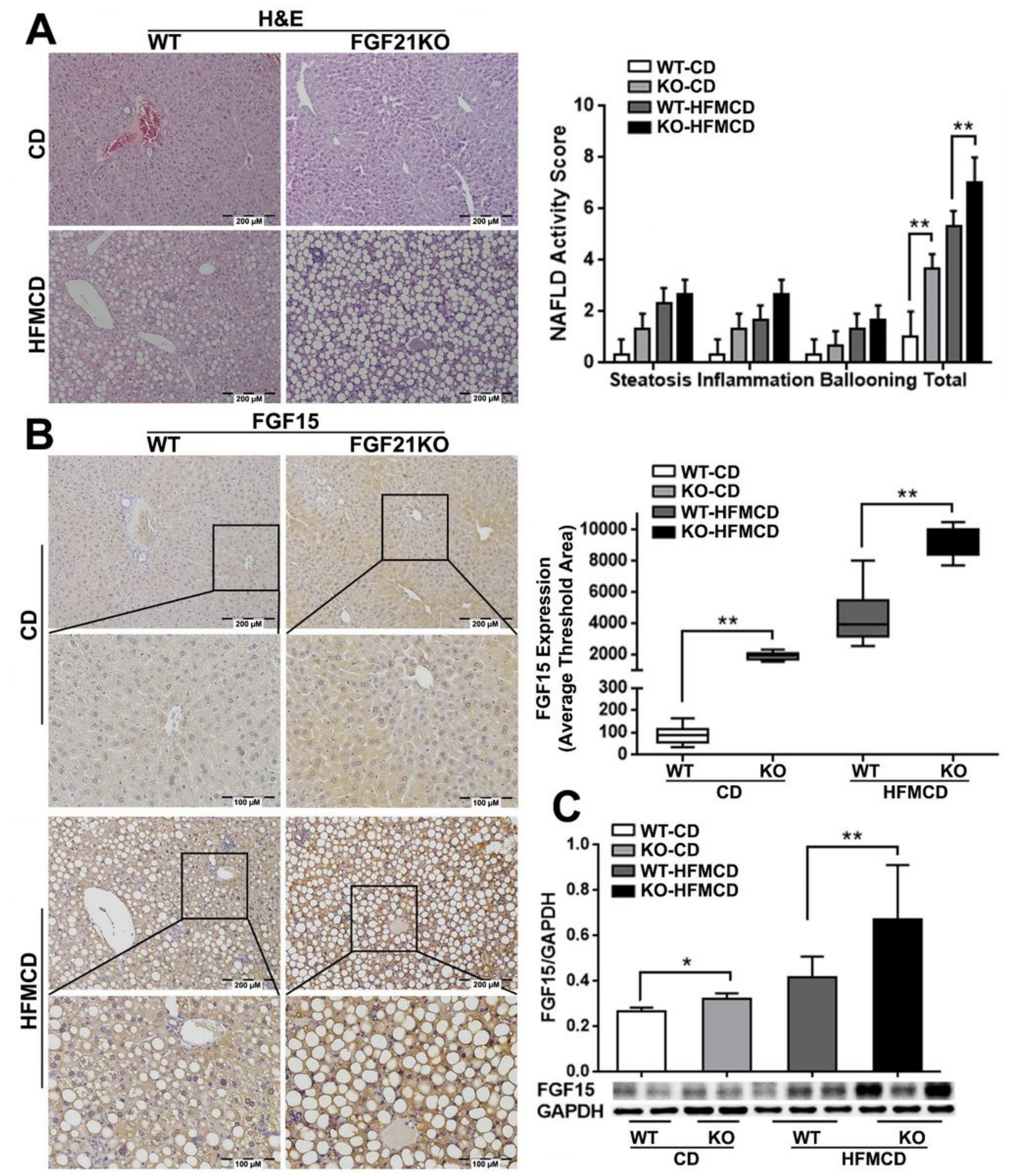

Figure 1

A: Representative histology by H\&E staining and NAFLD activity score (NAS) in the liver tissues from early NASH model and controls. For histological details, bland steatosis was characterized as wildly distributed lipid drops being detected while steatohepatitis was characterized as infiltration of inflammatory cells in the acinar zone and in the form of hepatocyte ballooning being detected. Scale bar=200 $\mu \mathrm{m}$. B: 
FGF15 expression by Western blot analysis in the liver tissues from early NASH model and controls. Upper: scale bar=200 $\mu \mathrm{m}$; lower: scale bar=100 $\mu \mathrm{m}$. WT: wild type; KO: FGF21KO; CD: control diet; and HFMCD: high fat methionine-choline deficient. *, $p<0.05 ; * *, p<0.01$.
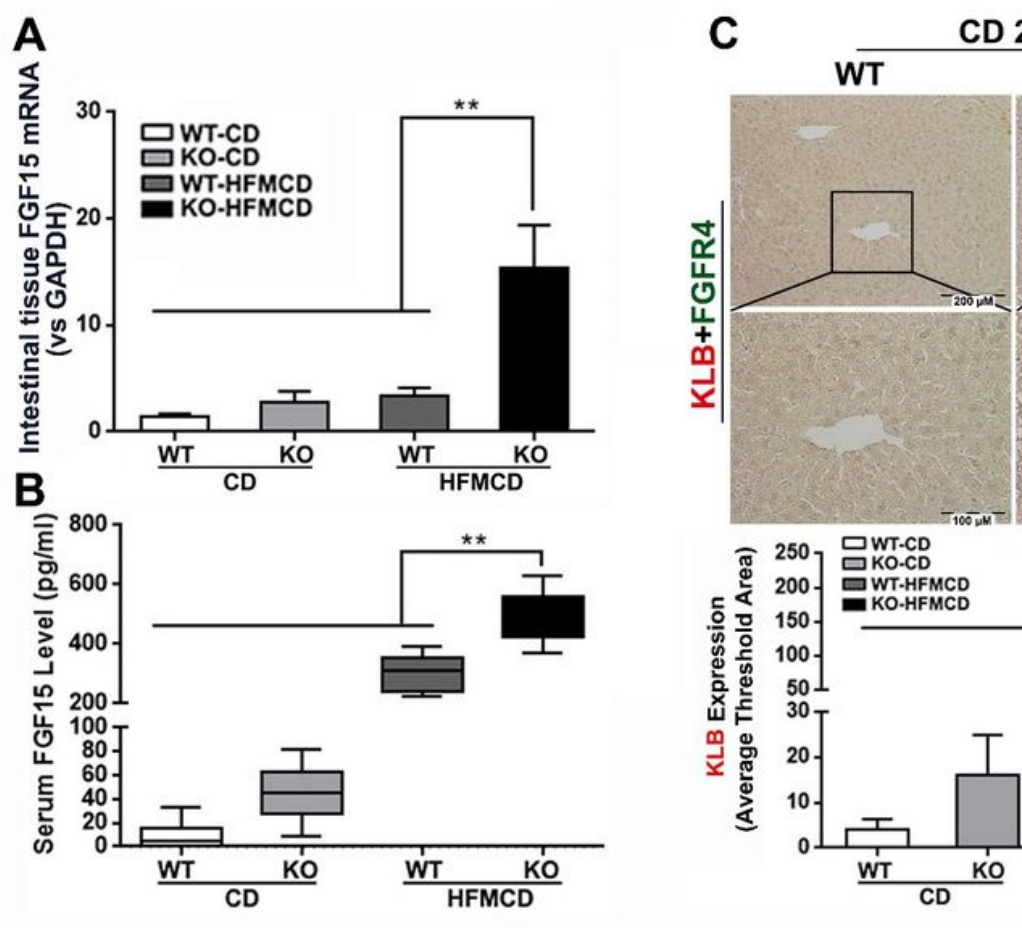

FGF21KO


Figure 2

A-B: FGF15 mRNA expression by qPCR in the ileum tissues and FGF15 protein levels by ELISA assay in serum from early NASH model and controls. C: Representative images of FGFR4/ $\beta$-klotho expression by a dual IHC staining along with computer-imaging analysis in liver tissues from early NASH model and controls. Upper: scale bar=200 $\mu$ m; lower: scale bar=100 $\mu \mathrm{m}$. D: FGFR4/ $\beta$-klotho mRNA expression by qPCR and FGFR4/ $\beta$-klotho protein levels by Western blot in the liver tissues from early NASH model and

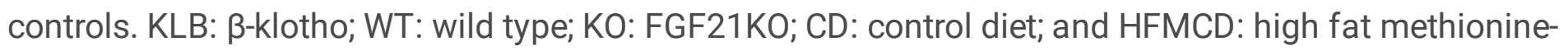
choline deficient. *, $p<0.05 ;{ }^{*}, p<0.01$. 


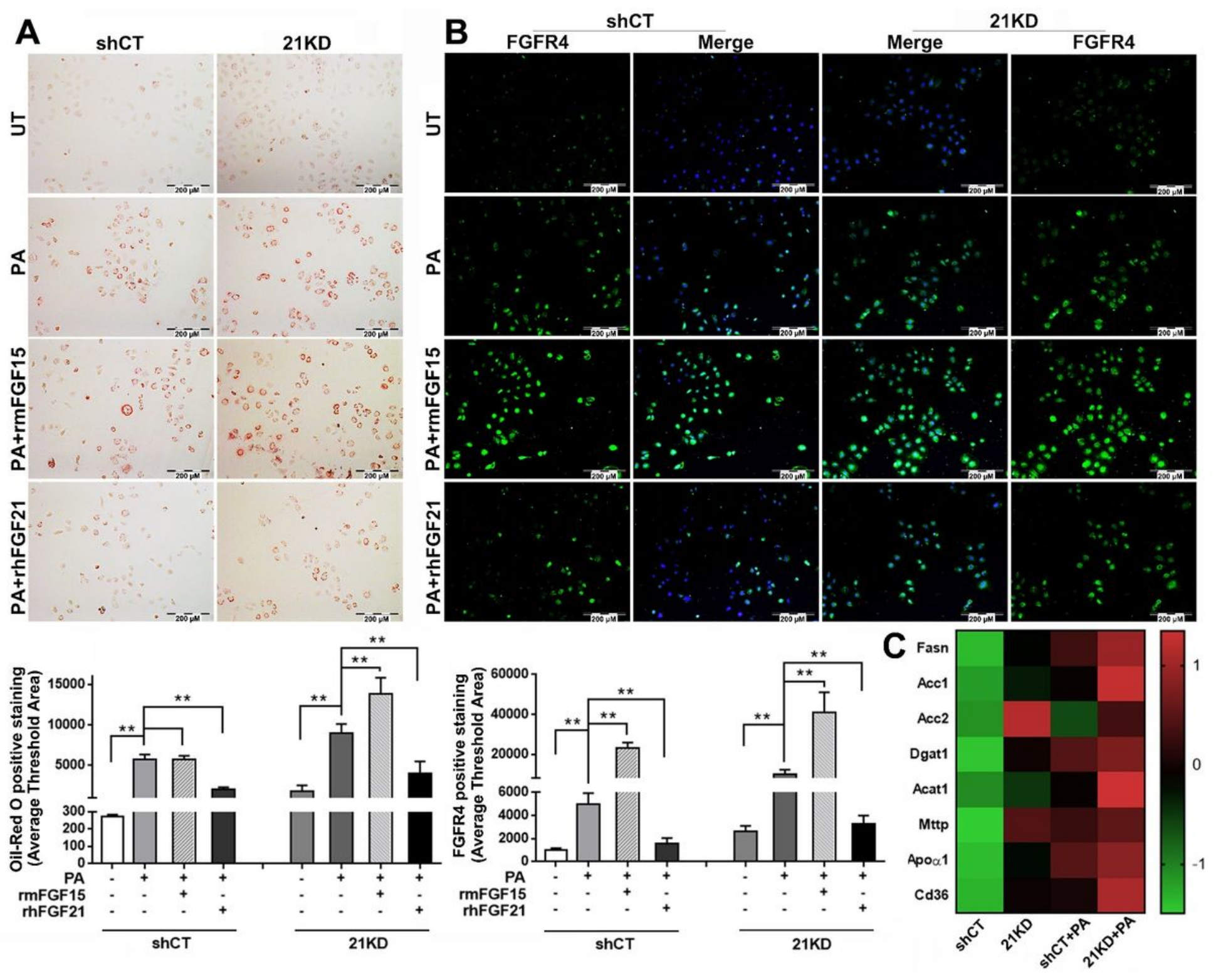

\section{Figure 3}

A: Lipid accumulation detected by Oil Red $O$ stain-ing along with computer-imaging analysis in shCTFL83B cells and FGF21KD-FL83B cells challenged with PA (palmic acid) at 100uM for 48 hours, and treated with rmFGF15 at 100ng/ml and rhFGF21 at $1.1 \mu \mathrm{g} / \mathrm{ml}$. Scale bar=200 $\mu \mathrm{m}$. B: FGFR4 expression detected by immunofluorescent staining in shCT-FL83B cells and FGF21KD-FL83B cells challenged with PA at 100uM for 24 hours, and treated with rmFGF15 at 100ng/ml and rhFGF21 at $1.1 \mu \mathrm{g} / \mathrm{ml}$. Scale bar $=200 \mu \mathrm{m}$. C: Alterations of lipid metabolic enzymes in shCT-FL83B cells and FGF21KD-FL83B cells challenged with PA at 100uM for 24 hours. FASN: Fatty Acid Synthase; Acc1: acetyl-coenzyme A carboxylase 1; Acc2: acetyl-coenzyme A carboxylase 2; Dgat1: Diacylglycerol acyltransferases 1; Acat1: Acyl-CoA:cholesterol acyltransferase 1; Mttp: Microsomal triglyceride transfer protein; Apoa1: apolipoprotein a-1. UT: untreated; PA: palmic acid; shCT: shCT-FL83B cells; 21KD: FGF21KD-FL83B cells. $\star *, P<0.01$. 

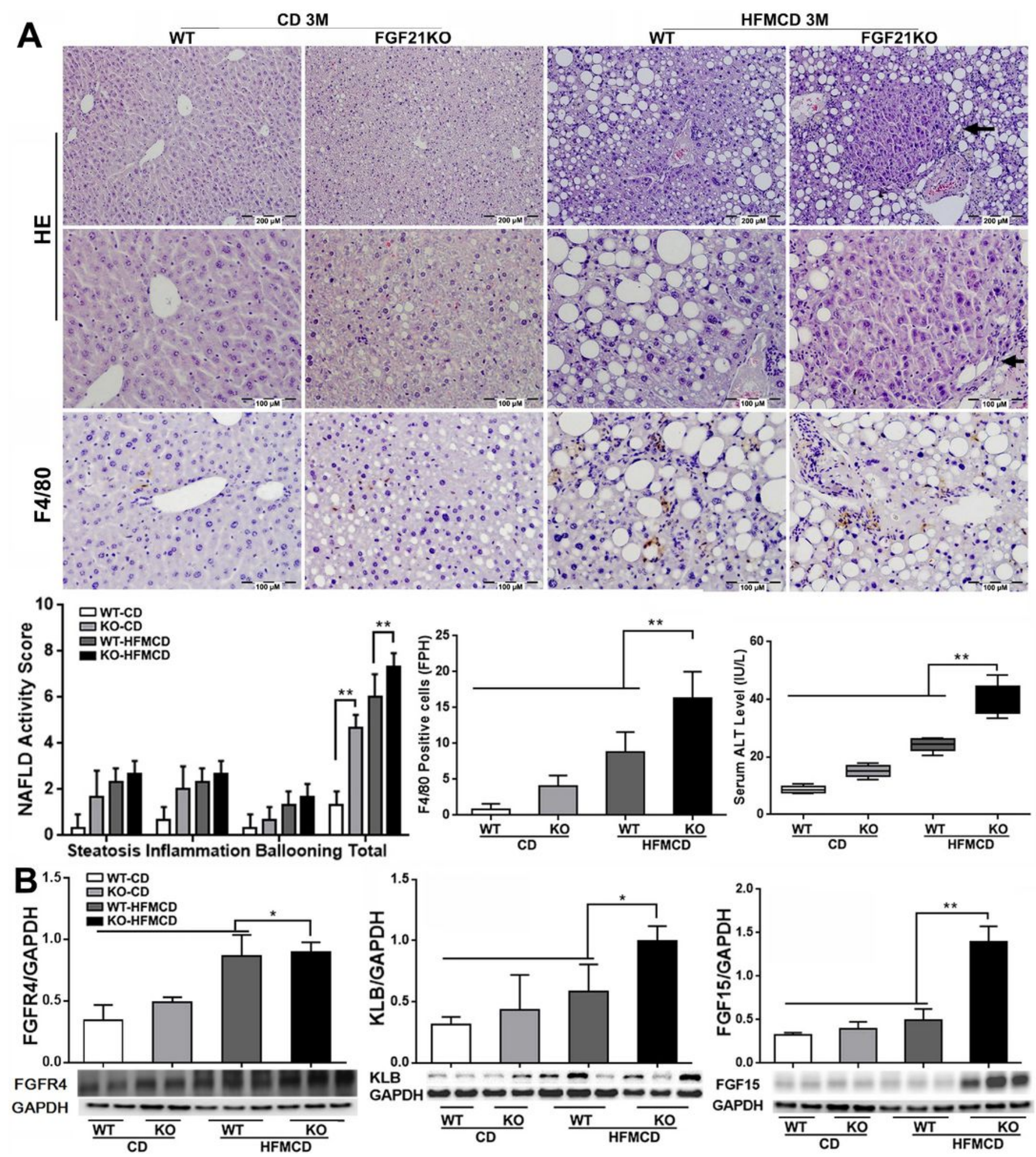

Figure 4

A: Representative histology by H\&E staining and Kupffer cells/macrophages detected by F4/80 staining in the liver tissues from advanced NASH model and controls. NAFLD activity score (NAS) and index of F4/80 positive cells were calculated based on H\&E and F4/80 staining. Arrow: a nodule was detected in the section by H\&E stain in hepatic parenchyma from FGF21KO+HFMCD mice. Upper: scale bar=200 $\mu$ m; Loading [MathJax]/jax/output/CommonHTML/jax.js Is of FGFR4, $\beta$-klotho and FGF1 5 by Western blot in the liver 
tissues from advanced NASH model and controls. KLB: $\beta$-klotho; WT: wild type; KO: FGF21KO; CD: control diet; and HFMCD: high fat methionine-choline deficient. FPH: field per high power. *, $p<0.05 ;$ **, $p<0.01$.

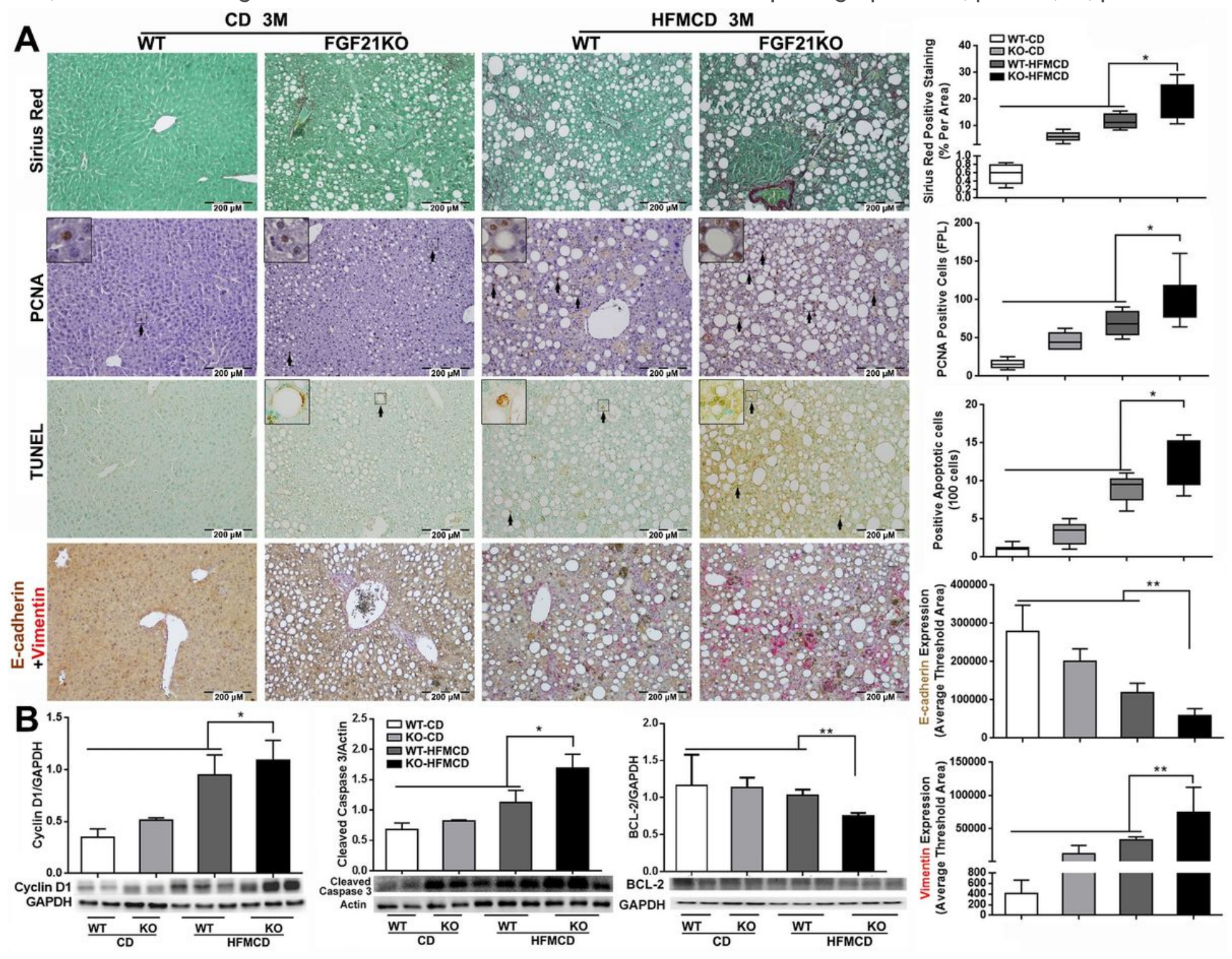

Figure 5

A: Representative images of Sirius Red staining, PCNA and TUNEL by IHC staining, E-cadherin/Vimentin by a dual IHC staining along with computer-imaging analysis in liver tissues from advanced NASH model and controls. Scale bar=200 $\mu \mathrm{m}$. B: Western blot analysis for the protein levels of cyclin D1, cleaved caspase-3 and BCL-2 in liver tissues from advanced NASH model and controls. WT: wild type; KO: FGF21KO; CD: control diet; and HFMCD: high fat methionine-choline deficient. FPL: field per low power. *, $p<0.05 ; * \star, p<0.01$. 
A

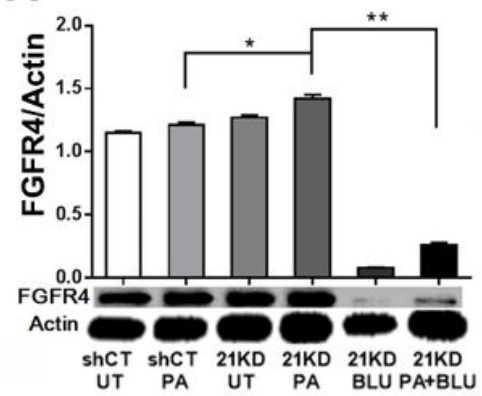

ShCT UT

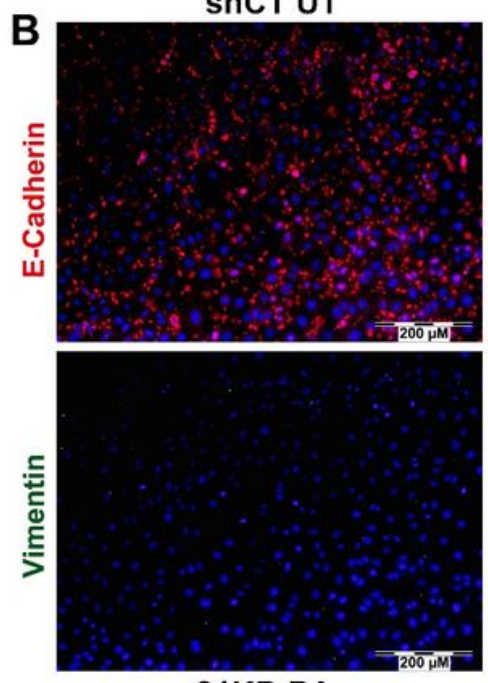

21KD PA
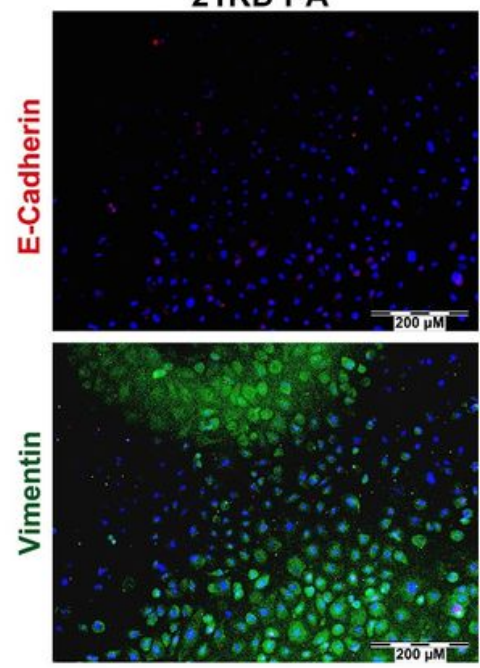

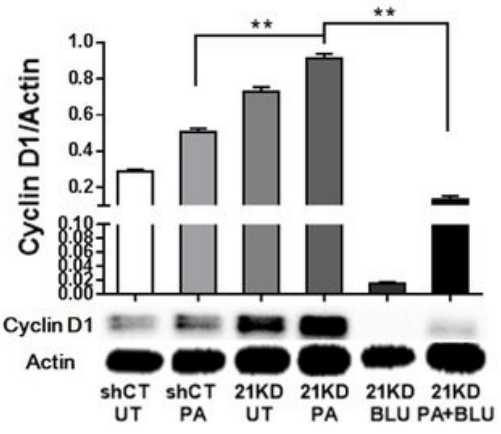

21KD UT
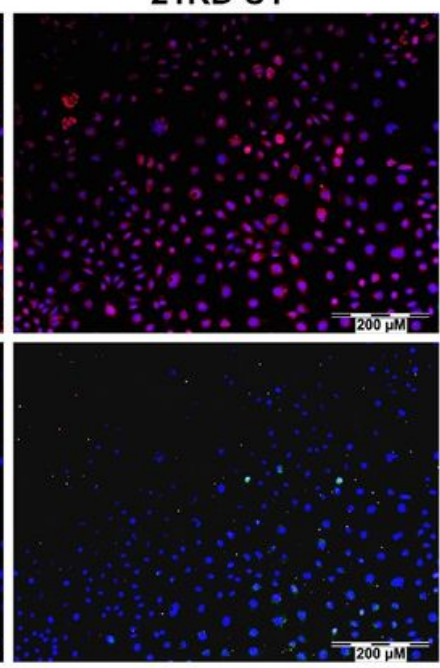

21KD BLU
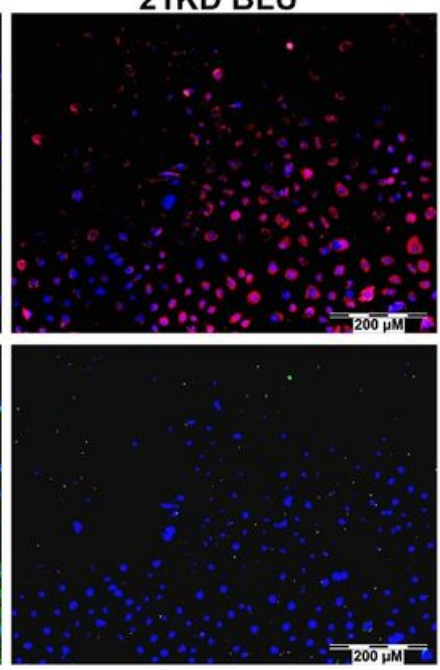

C

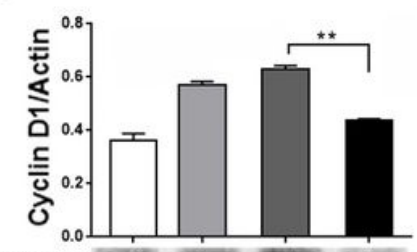

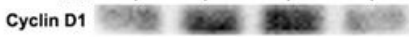

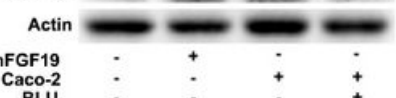

ShCT PA
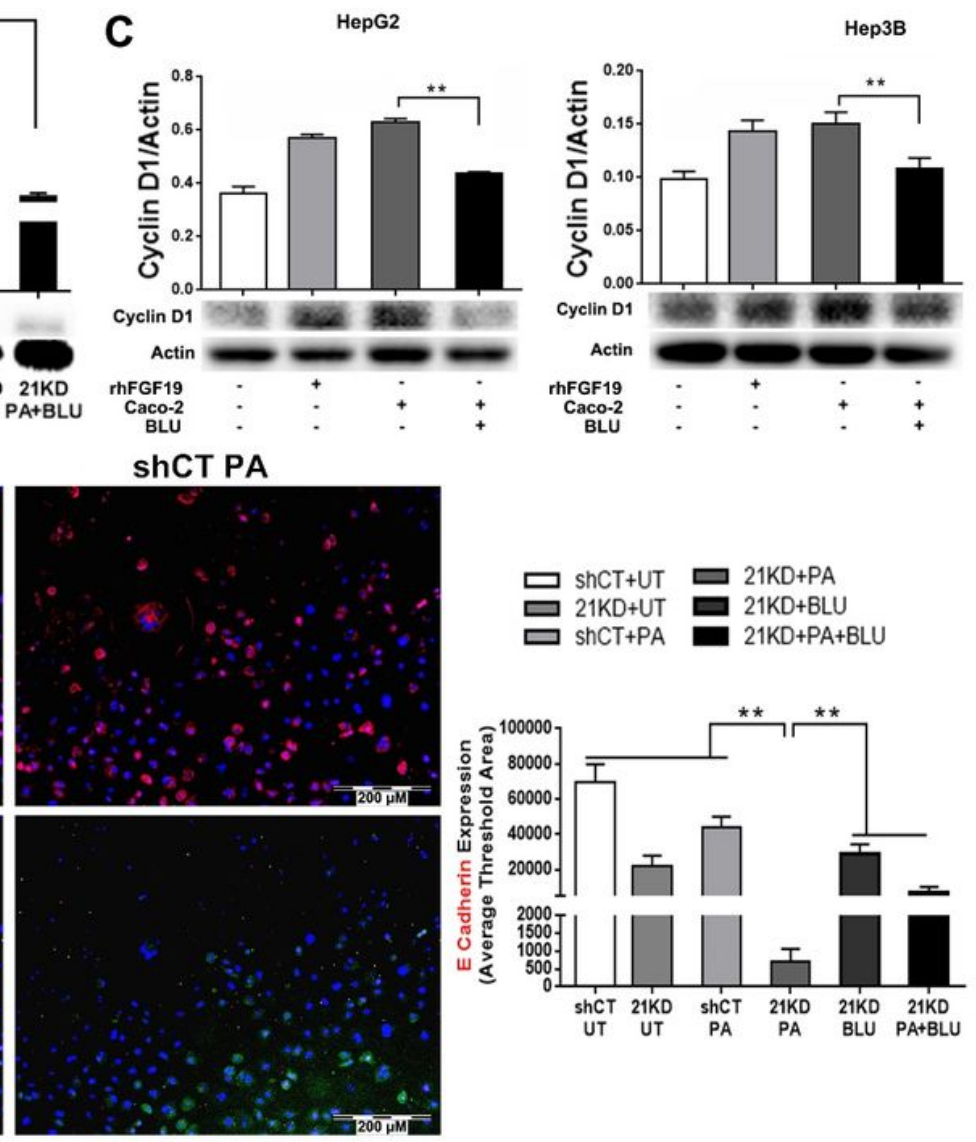

21KD PA+BLU

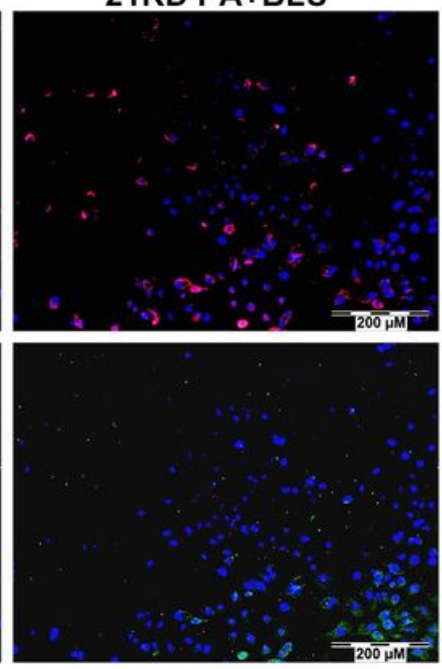

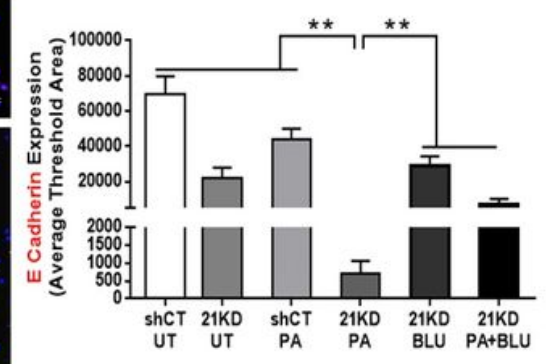

$\square$ ShCT+UT $\square 21 \mathrm{KD}+\mathrm{PA}$

$\square 21 \mathrm{KD}+\mathrm{UT} \square 21 \mathrm{KD}+\mathrm{BLU}$

$\square$ ShCT+PA $21 \mathrm{KD}+\mathrm{PA}+\mathrm{BLU}$

$\square$ shCT+UT $\square 21 \mathrm{KD}+\mathrm{PA}$

21KD+UT $21 \mathrm{KD}+\mathrm{BLU}$

$\square$ shCT+PA $21 \mathrm{KD}+\mathrm{PA}+\mathrm{BLU}$

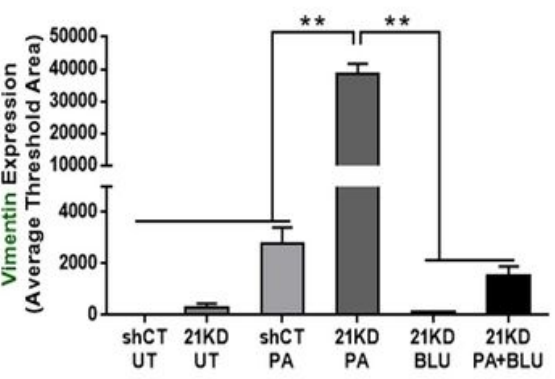

Figure 6

A: Western blot analysis for the protein levels of FGFR4 and cyclin D1 in shCT-FL83B cells and FGF21KDFL83B cells challenged with PA at 100uM for 24 hours, and treated with BLU9931 at 100nM for 24 hours. B: E-cadherin/Vimentin expressions by immunofluorescent staining in shCT-FL83B cells and FGF21KDFL83B cells challenged with PA at 100uM for 24 hours, and treated with BLU9931 at 100nM for 24 hours. Scale bar $=200 \mu \mathrm{m}$. C: Western blot analysis for cyclin D1 protein levels in HepG2 cells and Hep3B cells with rhFGF19 treatment at $100 \mathrm{ng} / \mathrm{ml}$ for 24 hours or with Caco- 2 cells co-culture for 24 hours. UT: untreated; PA: palmic acid; shCT: shCT-FL83B cells; 21KD: FGF21KD-FL83B cells. *, $p<0.05 ;$ **, $p<0.01$. 


\section{Supplementary Files}

This is a list of supplementary files associated with this preprint. Click to download.

- SupplementarymaterialsCM.docx 